\title{
Innovation in Corporate Organizational Culture: Diversity, Motivation and Organizational Pressure as Possible Realities
}

\author{
Innovación en la cultura organizacional \\ corporativa: una mirada humanista
}

DANIEL LÓPEZ

daniell@uhemisferios.edu.ec

\section{DANIEL SUSAETA ARANGO}

dsusaeta@ide.edu.ec

Abstract: A reflection is made on the culture of innovation within the company, which allows us to rethink the complexity of the creative action to innovate, which does not simply consist of the strategic definition of innovation on the part of management, but fundamentally depends on the human factor; its diversity, motivation and pressures of the company, so that the proposed objectives are achieved.

Keywords: Innovation, Organizational Culture, Change, Humanistic Enterprise
DiEgo ALEJANDRO JARAMILLO

diegoj@uhemisferios.edu.ec

Resumen: Se realiza una reflexión sobre la cultura de la innovación dentro de la empresa, que nos permite repensar la complejidad de la acción creativa para innovar, que no consiste simplemente en la definición estratégica de innovación por parte de la gerencia, sino que depende fundamentalmente del factor humano; su diversidad, motivación y presiones de la empresa, para que se logren los objetivos propuestos.

Palabras clave: Innovación, Cultura Organizacional, Cambio, Empresa Humanística 


\section{INTRODUCTION}

Innovation as a business management model has been positioned as a new paradigm for business strategy. Its effective implementation has depended fundamentally on the corporate organizational culture, in which the human factor is a determinant of the innovation strategy. In this line, a reflection is made on the role of that the culture of innovation plays within the company, and this is done through the lens of a Christian humanistic approach. In turn this allows us to rethink the complexity of the creative action to innovate, which does not simply consist of the strategic definition of innovation on the part of management, but fundamentally depends on the human factor, its diversity, motivation and demands of the company in order to achieve the proposed objectives.

\section{STATE OF THE QUESTION: INNOVATION AS A NEED FOR THE INTEGRATION OF DIVERSITY}

The concept of the humanistic approach that this paper deals with, comes from the Christian vision of mankind and the world; one where the human being, as a creature of creation, is understood as a free being, gifted with intelligence, free will, the ability to love and corporeity. It is from this vision that man is understood as the main character in the story of his life and of his own destiny. His nature, as a human being, encourages him as a rational man to seek the truth and it also guides him towards the understanding of the transcendence of life. This vision is not about an anthropocentric kind of humanism, where man is the creator of knowledge, and the owner of his own existence; it is not a vision where man uses other human beings and dispossesses them of their dignity. On the contrary, the Christian vision believes that each human being is unique and given his individual nature he is unrepeatable. In this vision, man is able to coexist and live in society in a peaceful and orderly manner, just as it belongs to his own social nature. Therefore, the individual seeks his own perfection and society looks towards achieving progress and human development.

The diversity of the human species arises from the very nature of the human being -the free being-, unique and unrepeatable as an individual. Likewise, the configuration of human groups, based on their ethnic conditions and beliefs, have constituted significant differences between them. 
And, it is precisely the need for collaborative work, despite human diversity $^{1}$, which allows the integration of knowledge of each other, which drives the need for experimentation, and which finally traces the disciplinary route of the innovation.

Contrary to what we suppose -a priori- diversity could hinder the cognitive integration processes required for the development of the innovation processes. Diversity seems to tend towards individualism ${ }^{2}$, and although undeniably, the great ideas that have constituted the inventions of humanity have been produced by individual initiatives, it is unquestionable that precisely, it is in the complement of human knowledge of both, that the advances of humanity towards their social and economic development have happened ${ }^{3}$.

Innovation is the human action of innovation, which derives from the superior faculty of the human being: intelligence, motivated by man's need for adaptation to his own environment. Its natural physical limitations in relation to the inclemency of nature, forces it to the permanent observation of the circumstances of the climate, the territory and, above all, the resources needed for its food and survival ${ }^{4}$.

However, it is necessary to specify that the action of innovation involves the application of empirical and abstract human knowledge -practical, theoretical-, to the problems of reality, through the design and application of tools -understanding as technical knowledge-, and, to the improvement of tools, such as technology 5 .

The possible origin of the action to innovate could be found precisely in the need to improve the tools developed by man to solve the problems offered by their natural habitat. This supposes the development of technology as an applied dimension of the theoretical-technical and practical-praxis-knowledge that derives in the act of being of innovating: innovation. In this line, Garzón (2005) conceives that all human intellectual action that involves the integration of theoretical, practical and technical knowledge, in order to improve a tool or a process assigned to the forms of human production is considered a productive action ${ }^{6}$.

\footnotetext{
Chinchilla, N. \& Cruz, H.(2010).

Rand, A. (1963).

Acs, Z. J.; De Groot H. \& Nijkam, P. (2002).

Attar, H. (2010).

Burns, T. \& Stalker, G. (1961).

6 Cohen, W. M. \& Levintha, D. A. (1990).
} 
Innovation over time has always required human experimentation. In turn this experimentation has been nourished by the experiences and conclusions of the individual and collaborative work of the members of the first peoples, despite their diversity. Through evolution, the social nature of man has allowed the exchange of knowledge ${ }^{7}$ among its members, both in determining moments of their own realities, as well as in the oral and written transmission between generations ${ }^{8}$. In this sense, the concept of innovation could be applied in all human dimensions, as a mechanism of change in the need for adaptation and subsistence, and that can be developed in its three types: evolution, revolution and transformation. As a factual example, the fact can be interpreted that from the homes the innovative process is initiated, from the preparation of the food, the construction and distribution of the home and the distribution of tasks, innovation processes have benefited the man from his own existence. However, this innovative process that arises as a need for adaptation for men completes its innovative cycle, with the transmission from generation to generation of this type of practices and knowledge and its improvement over time?.

The typification of change can be read from evolution, revolution, transformation and reaction. Evolution is that slow process, imperceptible in time that can be noticed as more from one generation to another. An example to our criteria has been the automotive industry since its inception, which has gradually been incorporating technological devices, which have slowly configured the automobile as we know it today. The revolution may be the change in which the structures of an organization are radically changed, but the institutional identity is maintained. A relevant example is the information revolution, the industrial revolution, and the French revolution itself. Companies could be considered a revolution in the changes that occur in the directions, when new policies are implemented that radically change the past assumptions in which the company moves ${ }^{10}$. Transformation happens when so many structures and the identity of institutions change dramatically. The constituent substance of the organization can be maintained, but both the structures and the identity change radically, the transformation takes place that gives rise to a new organization that is hardly similar to the initial organization. It is very

\footnotetext{
7 Argyris, C. (1999).

8 Macías Cardona, H. A. (2011).

9 Gant, J.; Ichniowski, C. \& Shaw, C. (2002).

10 Freeman, C. \& Soete, L. (1997).
} 
common for organizations that start processes of transformation of their business model to fail because they do not find an organizational culture that responds to the new demands of the business ${ }^{11}$. The reaction is the radical movement in the short term, which involves the forced action of the organization, motivated by a specific situation, and which determines the decision making by the company

The need for subsistence of the human species through hunting developed the concept of collaborative work, which allowed not only the preservation of the species but the dominance over other animal and plant species ${ }^{12}$. The passage from hunting to agriculture was one of the greatest historical milestones in the innovative action of man, considering that this change in human subsistence allowed the creation of cities and states, as we know them to this day. The domain of fire allowed man to adapt the inclemency of the cold to its forms of shelter from the home, cooking food, weapons of war, energy for transportation among others. The discovery of the wheel and the application of animal traction developed on the domestication of the horse allowed the expansion of the old empires through the conquest of generally inferior peoples in the development of their applied innovation ${ }^{13}$.

Adaptation to the environment does not in itself represent the engine of human innovation. On the contrary, the mere adaptation supposes numbness to a certain reality of the peoples. It is through crises that humanity and its peoples have found the need to innovate, which has forced it to incorporate changes in the determined action that is required. Thus, the shortage of food, the need for salt, climate change, the invasion of other peoples, among others, have all been causes of some of the deepest crises of humanity.

Crisis can be understood as a point of inflection and no return of a process in which, the criterion of efficiency does impairs the creative purpose of man; therefore rendering it obsolete and unbalanced in the harmonic order for which man mas designed ${ }^{14}$.

Change originates from the crises that occur in things and actions. The company cannot be considered a thing; on the contrary, it must be understood as a human action organized towards an end goal, which keeps it conti-

11 Kotter, J. (1996).

12 Nelson, R. \&Winter, S. G. (2002).

13 Fayol, H. \& Taylor, F. (1987).

14 Weick, K. E.; Sutcliffe, K. M. \& Obstfeld, D. (2005). 
nuously moving. The company is therefore not a finished action but instead it is ever dynamic and consequently it must be understood as being in permanent movement and change. It is precisely the movement inspired by business that is able to overcome crises. The crisis can be understood as a scenario of chaos, in which uncertainty reigns; it is the uncertainty of the decisions that must be taken around a specific situation that is created by chaos and crisis ${ }^{15}$. It is in these cases of crisis that managers must use their own experience and knowledge to choose a better path to follow. Finally, in this process managers must find ways to reduce risks, maintain the order and to convene the commitment of all members of the company.

\section{THE MOTIVATION FOR CHANGE, THROUGH COLLABORATIVE WORK AS A DETERMINANT OF INNOVATION}

After addressing culture and an imminent need for innovation to survive the aggressive environment that globalization and technology impose on us, we come to a manifest need for change. In this sense, change must be understood as a necessary step for man to achieve his goals which in turn should also mean an actions towards achieving self improvement; nevertheless, this is the kind of change that tends to cost the most in the long run. Speaking of an organization that addresses innovation means a change in its culture, which is the most complicated change that exists. And it is not just a glimpse of the future, something we can plan, but not predict; It is fundamental to understand that change is a process that must be analyzed carefully, and that before launching into what could be an imminent failure, we must analyze all the possibilities that this implies. The first thing is to understand the type of organization that we are. According to Juan Antonio Pérez López, there are three models that lead to a type of motivation: Mechanical, Psychological and Anthropological, which consequently involve in three motivations: Extrinsic, Intrinsic and Transcendent ${ }^{16}$. The problem is that all the actions of the organization are independent of the Model and it does not exactly work in a straight line. For example, if our model is Mechanical, the motivation will be Extrinsic, therefore, Autocratic leadership will be necessary. If the Leadership

15 Schumpeter, J. A. (2002).

16 Pérez López, J. A. (1985). 
in this model is of Consensus, a dissonance will be created in the direction of people and the objectives will fail. It happens also if we are in an Anthropological model, with a Transcendent motivation and the Autocratic boss shouts and makes decisions on his own, the organization will fall apart and probably give up good employees. In this case, the change also obeys the model and the motivation, so that it is not condemned to failure. The problem is that human beings are not stable in the same motivation, and external and internal elements affect our commitment to the organization. A family problem, a discussion with a partner, an economic problem, or even the problem of a partner with one of the bosses will be enough to change our state. Also, the type of leader affects the motivation within the same company, and this situation of different leadership in the same company reflects a weak culture. Without importing the character of the Leader, it must be adapted to the culture that the organization promotes. Let's see the following table based on the theory of Antonio Pérez López, IESE professor and proposed by Diego Alejandro Jaramillo, professor at IDE Business School, product of experience as Rector of the University of Los Hemisferios, in the area of people management:

\section{Table 1. Practical Aplication of the Theory of Motivations}

\begin{tabular}{|l|l|l|l|l|l|l|l|}
\hline Model & Motivation & Leadership & Comunication & Change & Learning & Strategy & Innovation \\
\hline Mechanic & Extrinsic & Autocratic & Falling & Drastic & Null & Operative & $\begin{array}{l}\text { Constant } \\
\text { improvement }\end{array}$ \\
\hline $\begin{array}{l}\text { Psychological } \\
\text { Organic }\end{array}$ & Intrinsic & Consensus & $\begin{array}{l}\text { Descending and } \\
\text { Ascending }\end{array}$ & Foretold & Technical & $\begin{array}{l}\text { Conventional } \\
\text { Prospective }\end{array}$ & $\begin{array}{l}\text { Closed to } \\
\text { Radical }\end{array}$ \\
\hline Anthropological & Transcendent & Assertive & Multidirectional & Continuous & $\begin{array}{l}\text { Technical } \\
\text { Formative }\end{array}$ & $\begin{array}{l}\text { Disruptive/ } \\
\text { Culture } \\
\text { Organizational }\end{array}$ & $\begin{array}{l}\text { Open } \\
\text { to } \\
\text { Disruptive }\end{array}$ \\
\hline
\end{tabular}

Chart made by the author from an adaptation of the model and types of motivations of Pérez López.

The first step is to determine in which of the rows of the table the collaborator is identified. This will tell us if we should apply a drastic, planned or continuous change. That decision also brings us to the type of strategy and innovation that we must use in this process. You can make an organization move from one model to another, but it must be gradual, without skipping a model. On the other hand, we should not prescribe any of the models all obey complex situations inherent in each organization. In some cases, moving from 
one model to another requires planning and strategy, with specific objectives. For example, if I need an imminent change, that is, drastic, because I foresee a crisis, or we must change the culture for some reason, then we move on the Mechanical Model, we dismiss some people, we generate a descending communication, without the right of reply, and then Once the objective has been achieved, we return to the previous model. It is risky, hard and even cruel, but it works in environments where people are governed under the control and pressure of supervision.

Following the proposed motivation categories of Pérez (1985), collaborative work could be the transcendental motivation towards mutual service. This in turn overcomes the intrinsic and extrinsic motivations of the individual and in addition this could be sufficient motivation for all innovation ventures.

In previous lines, we saw how the need for subsistence of the human species through hunting developed the concept of collaborative work, which allowed not only the preservation of the species but the dominance over the other animal and plant species. An organization is the result of joint work and collaborative work, indispensable for any organization, in which all the capacities and talents of people are added, with a common goal ${ }^{17}$.

To understand the scope of collaborative work within organizations, it is necessary to specify that within the organizational process the collaboration of all individuals for the achievement of organizational objectives becomes the natural dynamics of innovation, in which all are added the capacities of individuals to achieve an end. Without motivation on the part of individuals, innovation processes cannot be carried out ${ }^{18}$.

The projects of innovation of the organizations do not obey solely to material or technological changes, but necessarily involve social and cultural changes that determine and involve the individuals, and that depend on their own interests and motivations, factors that condition the success of the innovation and the impact on the culture of innovative companies ${ }^{19}$. However, within collaborative work, it is proper to approach human capacities, which are precisely -for their particularity- different and complementary ${ }^{20}$.

17 Daft, R. (1978).

18 Drucker, P. (1995).

19 Wenger, E. (1998).

20 Tsoukas, H. \& Chia, R. (2002). 
In their conceptual framework, Teece, Pisano and Shuen (1997) ask what kind of people is capable and willing to work as a team, and that they can generate innovation processes. In their approach, they define that the innovative intentions of companies are aimed at mobilizing not only necessary financial resources, but also to motivate people to cooperate with each other in the implementation of innovative strategies, regardless of the hierarchical and functional division, to which Edquist, Hommen and McKelvey (2001) called the social conditions of innovative companies. The perspective of both is based on the fact that the company seeks to grow using the collective process and consequently the accumulation of knowledge directed towards innovation. However, it is necessary to specify the conditions of the motivational strategy, and the possible impacts on the individual and the collaborative work of the company. The perspective also emphasizes the role of the human dimension, determining through it, how the company accumulates innovative capacity, and adds an explicit social dimension to work on its innovative dynamic capacities ${ }^{21}$.

Within collaborative work it is necessary to specify the role of individual capacity, and that could guarantee innovative processes, focusing on the particular capabilities of each, regardless of the hierarchical position within the company, which understandably includes strategic managers ${ }^{22}$.

On the other hand, learning within collaborative work is fundamental in business innovation, and could be constituted as an intrinsic motivational factor of people. Learning, in the case of collaborative work, must obey individual and collective management processes, of central importance on the accumulation and transformation of knowledge capacities ${ }^{23}$

In innovation processes, not only technical concepts are involved, but also social, cultural and economic processes, in such a way that collaborative work acquires significant value, since those who generally have high expectations when faced with innovation processes, they are the members of the teams themselves ${ }^{24}$. For its part, the company must build and develop the appropriate structural conditions for its motivational strategic innovation. There are political, social and cultural elements that typify all human action, as well

21 DeYoung, R. (2005).

22 Fagerberg, J. \& Godinho, M. (2005).

23 Feldman, M. S. (2000).

24 Foss, K.; Foss, N. \& Vasquez, X. (2006). 
as their experiences and beliefs ${ }^{25}$. All these elements are present in human motivation and define each human and social situation as unique and unrepeata$\mathrm{ble}^{26}$. In collaborative work, companies fundamentally align all human actions towards a common objective, in which the acceptance of the actors is achieved, through motivation and other elements, and that in the end they summon people towards the development of innovative projects ${ }^{27}$.

The motivation in the collaborative work must be identified precisely from the joint work of those in the company, in the end this tends to determine its organizational culture ${ }^{28}$. Organizations have the power to influence their collaborators, constituting by that the force that explains human motivation within the organizational framework; which would in turn explain one of the reasons why a person is able to act on behalf of a group or an organization $^{29}$. Participation in group work acts turns into a motivating force to achieve desired for changes in the organizations and their people.

It could hardly be conceived of innovative companies without deepening their organizational culture. For Kline and Rosenberg (1986), the organizational culture is the basis for the success of innovation projects.

Culture is the way we do things one way or another. According to Mathew, the organizational culture is a constitution based on the common beliefs shared by certain human groups, which become their dominant patterns of behavior and values ${ }^{30}$.

Scheine defines that "organizational culture is the pattern of basic premises that a certain group invented, discovered or developed in the process of learning to solve their problems of external adaptation and internal integration and that worked well enough to the point of being considered valid and appropriate to be taught to new members of the group as the correct way to perceive, think and feel in relation to these problems ${ }^{31}$.

The innovative culture is the modus vivendi of a certain group of people that revolves around the development of the improvement of tools, products

25 Gherardi, S.; Nicolin, D. \& Odella, F. (1998).

26 Orlikowski, W. J. (1996).

27 Nonaka, I. \& Takeuchi, H. (1995).

28 Dutton, J. E. \& Dukerich, J. M. (1991); (Gioia, D. A.; Schultz, M. \&Corley, K. G. (2000).

29 Albert, S.; Ashforth, B. E. \& Dutton, J. E. (2000).

30 Mathew; G. E. (2010), p. 21.

31 Scheine, E. H. (1998) p. 56. 
or processes. It also supposes the joint work in the consecution of a common objective, that of innovating ${ }^{32}$. For companies, the organization of these groups and their respective government and direction towards the achievement of effective results implies the greatest organizational effort, every time, in the innovation process multiple frictions can appear between the members of the groups.

The cultural system of an organization, or organizational culture, is fundamental and practically determining for the achievement of innovative projects. Mumford and Simonton (1997) consider that the companies that give value to their innovative processes and involve in them the collaborative work, the valuation and independence of the human resource, manage to develop successful innovative projects. In the same line, Rycroft and Kash (2002) consider that only companies that have a strong innovative culture, can withstand the pressures of the environment, not only as the only option of competition, but of survival. In organizations in which a structured organizational culture is observed, organized and coherent with the policies of the company, in which there are similar sociocultural behaviors among its employees, trust and a certain competitive responsibility, a favorable performance can be observed in front of the processes of innovation.

Although what we think others say about us, about how they see us, is an engine for action, it is not enough. It is necessary to deepen within our individual and group identity, because beyond what others think, is our ultimate reason. The beliefs, opinions or motivations of the person are the drivers of action and this depends on the person opting for alternatives instead of others and make the decision even if it is not the best option, because in doing, the right thing sometimes it implies costs ${ }^{33}$. To comprehensively examine our beliefs in the light of the foundations that sustain them requires a spiral process through stages of appreciation, action and re-appraisal that entails an effort that brings positive, neutral or negative consequences, and that ultimately entails responsibilities personal and social for those who execute them.

The ultimate goal of reflective thinking ${ }^{34}$, in addition to differentiating ourselves from animals, is what allows us to build abstractions and inventions, give meanings to things to possess greater control and potential capacity to

32 Mintzberg, H. (2007).

33 Argyris, C. \& Schon, D. A. (1974).

34 Dewey, J. (1933). 
do for their accumulation. So, the intensity of the moment that is lived and/or the virtuosity of prudence used in the action together with the definition of the ultimate goal of the action, are elements that affect the person in the world, such as the learning process (what you learn or not), the acquisition of new knowledge and the result of the practice.

All these events occur both in the field of people as well as that of organizations. Some authors affirm that organizations have identity ${ }^{35}$ and that this identity influences the actions of their individuals, the interpretation that each of them gives to the organization's questions and in turn the behavior in front of them. What others think about an organization, ie the image, is what usually causes a need for change ${ }^{36}$ and constitutes a force that explains the agency human within the organizational framework, and explains one of the reasons why an individual is able to act on behalf of a group or an organization $^{37}$.

\section{DISCUSSION: THE PRESSURES OF INNOVATIVE CHANGE}

We understand that the pressures that companies perceive to initiate or continue innovation processes respond to different causes. However, it could be argued that the need for competition and survival in the markets could be the two main causes of motivation. We define pressure, inasmuch as it is not necessarily an intrinsic motivation of the organization, but on the contrary, an extrinsic motivation, which finally, can become a determinant of its existence.

Carlota Pérez (2001) points out that "despite their specific variations, a large part of the technologies tends to follow a similar trajectory in terms of the pace and direction of change and the improvements from initial innovation to maturity, an evolution that coincides approximately with that of their markets: from introduction to saturation".

There is a coincidence in the innovation literature that the great generator of change, and why companies look for innovative processes, has been the constant technological pressure to which the modern world is exposed, mainly due to the globalization of markets and the globalization of companies themselves ${ }^{38}$.

35 Albert, Stuart and Whetten, D. A (1985); Ashforth, B. E. \& Mael, F. (1989).

36 Dutton, J. E. \& Dukerich, J. M. (1991); (Gioia, D. A.; Schultz, M. \&Corley, K. G. (2000).

37 Albert, S.; Ashforth, B. E. \& Dutton, J. E. (2000).

38 Pérez, J. A. (2001). 
The following graph shows the life cycle of technological innovation, in which Nelson and Winter (2002), Freeman (1982) and Pérez (1985) coincide in four fundamental phases, in which the innovative process is exposed to a period of decrease, which is a critical state, conducive to change, and to restart a new process of innovation.

\section{Graphic 1. Cicle of Life of the Techonological Evolution}

\section{The evolution of a technology: A technological trajectory}

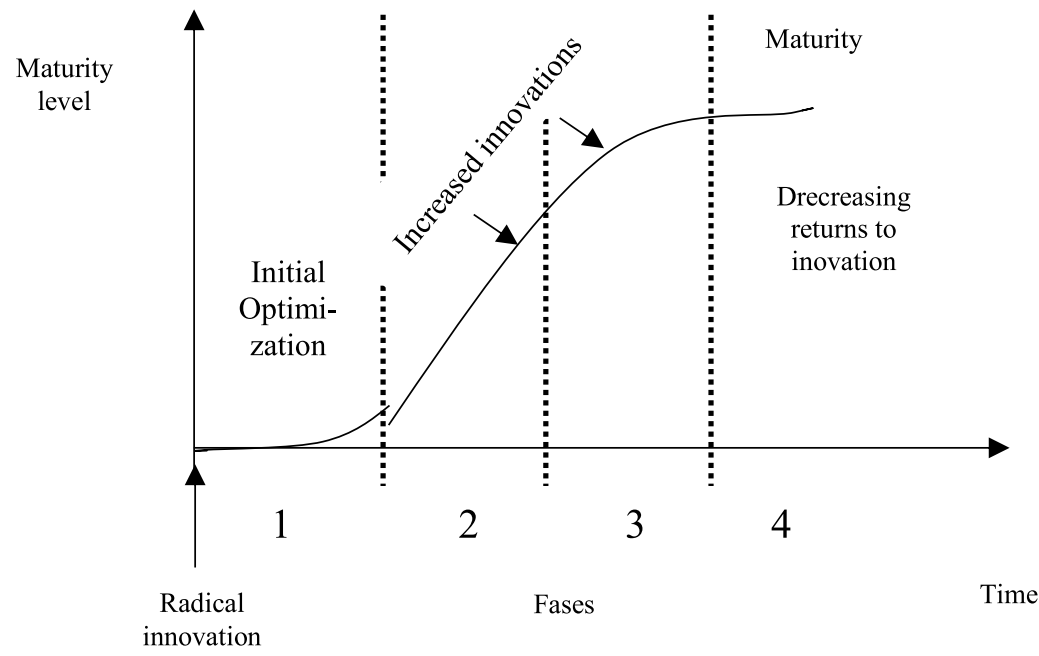

Own elaboration based on Nelson, R. R. \& Winter, S. G. (2002); Freeman, C. (1982) and Pérez, J. A. (1985).

The change brings with it, the opportunity to provide those who live it a new learning process, the same that can produce new ideas and projects. The change can be seen as an immanent need of human organization, as its dynamics of constant movement. Nothing is lasting, everything evolves, is revolutionized or transformed. Innovation can be the cause or the consequence of change; this depends on the stage in the life cycle in which the process finds itself. Every innovation process involves a method or technique to achieve this, even when it may not appear in an exponential way ${ }^{39}$. All innovation pro-

39 Kanter, J. (1984). 
duces changes, and any change could potentially produce an innovative action. This in turn will depend on the creative and innovative aptitude of those who are the protagonists and the responsible ones to carry it out ${ }^{40}$.

Companies are forced to make changes, according to the needs, demands and preferences of consumers, their own members, or pressure from some of their stakeholders that come from varied and diverse behaviors ${ }^{41}$. This phenomenon causes companies to adapt their organizational structure to respond to the competitive demands of the market. Seen in this way, companies design innovative strategies when they point to products with which they want to compete, and with the technologies with which they expect to be competitive. The companies invest substantial efforts in transforming innovative technological processes, and even more structural changes, which suppose significant investments, considering that the innovation process supposes an effort parallel to the core of the business ${ }^{42}$.

According to Schumpeter (2002), the competitive complexity of the world constantly brings the need for the evolution of companies to survive, which generates the need for organizational change, and the need to differentiate themselves in the midst of the immense ocean of commercial possibilities. In its interaction with the world, organizational differentiation is the first interface that acts in the organization and serves to perceive and interpret it. Organizational differentiation arises from organizational identity, according to the concept of Albert \& Whetten ${ }^{43}$, in his book Organizational Identity, is what the organization thinks of itself, what it believes to be, and what gives shape to what he puts into practice. This identification provides a large part of the forces necessary to undertake innovation processes ${ }^{44}$. The organizational change is based on the practices of each day and depends on each of the actors of the organization. Tsoukas \& Chia define the change as the reweaving of the organizational actors on the sets of beliefs and habits to accommodate the new experiences obtained through the interactions with the world ${ }^{45}$.

40 Ettlie, J. (1986).

41 Prats, $\mathrm{M}^{\mathrm{a}}$ J.; Siota, J.; Canonici, T. \& Contijoch, X. (2018).

42 Lazonick, W. \& O'Sullivan, M. (2000).

43 Albert, S. \& Whetten, W. A. (1985).

44 Orlikowski, W. J. (1996)

45 Tsoukas, H. \& Chia, R. (2002). 
The need for change generates pressures in organizations. The breaking point could be one in which the organization, through its members, warns that a certain process or product does not meet its initial objectives ${ }^{46}$. From this trigger the process of organizational change begins. It is then sought to establish new beliefs based on empirical evidence and rationality, which consists of learning to do things differently ${ }^{47}$. During this process of organizational re-learning, a series of iterations are carried out between what is perceived by experience and the reflective processes of the understanding of individuals ${ }^{48}$. During these learning processes, the knowledge acquired in the past is used as tools in the exploration process, giving shape and discipline to that process; all this, for the learning of new knowledge ${ }^{49}$.

When organizational learning generates new practices that solve existing needs, these are consolidated by becoming institutionalized in new cognitive representations that provide better solutions to present problems, giving meaning, coherence and form to the new organization, given that it is finally the result of this construction ${ }^{50}$. Additionally, these new practices are possible, thanks to the configuration of new forms of consumer and market interpretation $^{51}$. Without this organizational creation, the innovation process can't be consolidated $^{52}$. Schumpeter calls this phenomenon a process of creative destruction.

The companies and organizations that live in the competitive world, see the need to carry out productive processes and increasingly competitive and more efficient products ${ }^{53}$. It is clear that any organization that performs innovation processes obeys the current patterns required by competition, competition that drives companies to improve in all structural aspects and to transform production processes.

All the changes that are generated in an organization derived from innovation processes, inevitably lead to a series of implications that involve all related personnel. In this way, the company must be prepared to multiply trai-

\footnotetext{
46 Dewey, J. (1933).

47 Elkjaer, B. (2005).

48 Pedler, M. J.; Boydell, T. \& Burgoyne, J. (1989). Easterby-Smith, M. \& Lyles, M. (2003).

49 Cook, S. \& Brown, J. S. (1999).

50 Weick, K. E.; \& Sutcliffe, K. M.\& Obstfeld, D. (2012).

51 Orlikowsky, W. J. (2002).

52 Van de Ven, A. H.; Polley, D. E.; Garud, R. \& Venkataraman, S. (1999).

53 Tsoukas, H. \& Chia, R. (2002).
} 
ning processes that guarantee compliance with innovation objectives ${ }^{54}$. The efficient result and the fulfillment of all the objectives set by an organization for the realization of evolutionary changes and innovation processes immerses the company in a world of competitiveness that is strengthened by external relations that benefit society and its members, in terms of improving the quality of life of people. In this regard, Valente and Rogers, consider that without innovation it is impossible for a company to adapt to the changes that occur in the commercial environment ${ }^{55}$.

There are many coincidences among the students of the organization, in which the pressure felt by companies on their innovation needs is precisely the engine of business improvement and growth ${ }^{56}$. Innovative companies are usually organizations that respond to a typical profile in which certain organizational behaviors can be distinguished. According to Van de Ven (1999) and Acs; De Groot \& Nijkam (2002) warn that, due to different pressures, companies that innovate are flexible, with an openness to their environment, oriented to the client and with some important points to their favor that establish a profile that helps them with their innovative projects, within these points, the aspect of human quality is relevant.

Currently, globalization and world market conditions demand quality standards from organizations, which involve all areas, departments, or nodes, and therefore all collaborators or workers ${ }^{57}$. These standards obey technical, technological, commercial, operative, etc. patterns which are the engine of companies to develop innovative projects. All processes developed and perfected in each organization determine their organizational culture and guide their objectives.

There is concern and questioning within the scholars of the subject, about the existence of an organizational prototype that defines innovative companies. Rycroft and Kash (2002) conceive of the company as an open sociotechnical system, in which the organization, through its members, show similar, homogeneous and coherent behaviors and practices, which are the result of strong structures, more solid processes and compelling innovative results $^{58}$.

54 Anderson, P. \& Tushman, M. L. (1990).

55 Valente, T. W. \& Rogers, E. M. (1995), p. 39.

56 Spender, J. C. (1996).

57 Pavitt, K. (2005).

58 Lank, E. \& Mayo, A. (2003). 
In general, innovation is only possible if there is full unity between the policies of the organization, the strategic objectives, in harmony with the organizational structure, and financial resources, through the support of ideas, the acceptance and motivation of employees, Knowledge management and all the factors and processes demanded by the innovation process ${ }^{59}$. However, within the success of innovation, it must be considered as a fundamental mechanism, elements strictly linked to the organizational culture, values and leadership that together lead and push the organization to achieve positive results and competitiveness.

Deal and Kennedy warn that the pressures that organizations have are very different from each other and distinguishes the memo three types of them, in which, by combining different cultural elements completely different organizations are obtained in their conformation. There are hard cultures where life is at risk, such as police institutions or the lives of surgeons ${ }^{60}$. Others, in which, on the contrary, play and work seem to mix. They are direct sales companies, for example. There, an unspecified sale does not endanger the life or permanence of the company. In a third group of organizations the risk is high, or the investment results are not seen in the short term, such as oil companies or aviation companies. In each of these cases the culture will be completely different and the needs to be covered as well. Both stories, rituals, heroes, gossip or values will be considered by leaders who have the responsibility to keep the culture of a company alive ${ }^{61}$.

\section{CONCLUSIONS}

Human diversity, contrary to what one might suppose, is a fundamental factor for the development of the innovative culture, given that it is precisely in the complementarity of knowledge that it is possible to establish the unity of work teams.

The motivation of the collaborators is fundamental for the achievement of innovation processes: it will be a determining task of the organization to find out what are the individual and collective motivations that facilitate the innovative work.

59 Kotter, J. (1996).

60 Allaire, Y. \& and Firsirotu, M. (1984).

61 Allaire, Y. \& and Firsirotu, M. (1984), p. 5. 
The categories of motivation proposed by Pérez-López are valid to design a model oriented to the development of innovation at any given business.

It could be said that in the beginning, innovation could be derived from the improvement of tools and technology. However, the action of innovating is applicable to all human dimensions, insofar as the permanent need for change is found in the processes of evolution, revolution and transformation.

By itself, adaptation to the environment does not equate to the motivation towards an innovative process. On the contrary, a crisis is required for a certain human group to leave their comfort zone and recognize their needs and their desire to innovate, as the only solution mechanism to that very crisis.

The sum of the skills and knowledge of a group of people is the ideal complement to form joint work teams, which in turn allows more sustainable innovation processes within the company.

The lifelong learning of people and teams allows innovation processes to be more efficient and effective. This in turn, can become the main driver of the motivation to achieve results.

In innovation processes not only the prior knowledge of people, but also their beliefs and positions that can facilitate or hinder the defined results.

Innovation is possible if there is coherence between structure, behavior and results, that is, between politics, culture and the final operation.

The pressure exerted by the organization on employees does not necessarily arise from the alignment of policies, culture and results; they also obey the core business of the organization, in terms of the risks they could pose to employees.

\section{BIBLIOGRAPHY}

Acs, Zoltan, J.; De Groot, Henri \& Nijkam, Peter (2002), The Emergence of the Knowledge Economy: A Regional Perspective, Springer, Baltimore.

Albert, Stuart and Whetten, David A. (1985), "Organizational Identity", in Staw, Barry M. \& Cummings, Larry L. (Eds.), Research in Organizational Behavior, JAI Press, Greenwich, pp. 263-295. 
INNOVATION IN CORPORATE ORGANIZATIONAL CULTURE: DIVERSITY, MOTIVATION AND ORGANIZATIONAL PRESSURE AS POSSIBLE REALITIES

Albert, Stuart; Ashforth, Blake E. \& Dutton, Jane E. (2000), "Organizational Identity and Identification Charting New Waters and Building New Bridges", Academy of Management Review, vol. 25, pp. 13-17.

Allaire, Yvan \& Firsirotu, Mihaela (1984), "Theories of Organizational culture", Organization Studies, vol. 5, n 3, pp.193-226.

Anderson, Philip \& Tushman, Michael L. (1990), "Technological Discontinuities and Dominant Designs: A Cyclical Model of Technological Change”, Administrative Science Quarterly, vol. 35, n 4, pp. 604-633.

Argyris, Chris \& Schön, Donald A. (1974), Theory in Practice Increasing Professional Effectiveness, Jossey-Bass Publishers, San Francisco.

Argyris, Chris (1999), Flawed Advice And The Management Trap: How Managers Can Know When They're Getting Good Advice and When They're Not, Oxford University Press, Oxford.

Ashforth, Blake E. \& Mael, Fred A. (1989), "Social Identity Theory and the Organization", Academy of Management Review, vol. 14, n 1, pp. 20-39.

Attar, Hooman (2010), The Dance on the Feet of Chance, Ebook Xlibris.

Burns, Tom \& Stalker, G. (1961), The Management of Innovation, University of Illinois at Urbana-Champaign's Academy for Entrepreneurial Leadership Historical Research Reference in Entrepreneurship, Chicago.

Chinchilla, Nuria \& Cruz, Hugo (2010), "Diversidad y paradigmas de empresa: un nuevo enfoque", Revista Empresa y Humanismo, vol. 14, n 1, pp. 47-79.

Cohen, Wesley M. and Levintha, Daniel A. (1990), "Absorptive Capacity: a New Perspective on Learning and Innovation", Administrative Science Quarterly, vol. 35, pp. 128-152.

Cook, Scott D.N. \& Brown, John Seely (1999), "Bridging Epistemologies: The Generative Dance between Organizational Knowledge and Organizational Knowing", Organization Science, vol. 10, n 4, pp. 381-400.

Daft, Richard (1978), "A Dual-Core Model of Organizational Innovation”, Academy Of Management fournal, vol. 21, n² 2, pp. 193-210.

Deal, Terrence, \& Kennedy, Allan (1985), Las empresas como sistemas culturales: Ritos y rituales de la vida organizacional, Sudamericana, Buenos Aires.

Dewey, John (1933), How We Think: A Restatement of the Reflective Thinking to The Educative Process, Heath, Boston. 
DeYoung, Robert (2005), "The Performance of Internet- Based Business Model”,. Fournal of Business, vol. 7, n 3, pp. 893-947.

Drucker, Peter (1995), La nueva sociedad de organizaciones, Truman Talley Books, New York.

Dutton, Jane E. \& Dukerich, Janet M. (1991), "Keeping an Eye on the Mirror: Image and Identity in Organizational Adaptation", Academy of Management fournal, vol. 34, $\mathrm{n}^{\circ}$ 3, pp. 517-554.

Easterby-Smith, Mark \& Lyles, Marjory A. (2003), "Organizational Learning and Knowledge Management: Agendas for Future Research", in (2011), The Blackwell Handbook of Organizational Learning and Knowledge Management, Blackwell, Oxford.

Edquist, Charles; Hommen, Leif \& McKelvey, Maureen (2001), Innovation and Employment: Process versus Product Innovation, Edward Elgar Publishing, Cheltenham.

Elkjaer, Bente (2005), "From Digital Administration to Organizational Learning", Fournal of Workplace Learning, vol. 17, nº 8, pp. 533-544.

Ettlie, John E. (1986), "Innovation in Manufacturing" in Gray, D.O.; Solomon, T. \& Hetzner, W. (Eds.), Technological Innovation, Elsevier Science Publishers B.Y, North Holland, pp. 135-144.

Fagerberg, Jan \& Godinho, Manuel (2005), "Innovation and CatchingUp", en The Oxford Handbook of Innovation, Oxford University Press, Oxford, pp. 514-543.

Feldman, Martha S. (2000), "Organizational Routines as a Source of Continuous Change”, Organization Science, vol. 11, nº 6, pp. 611-629.

Foss, Kirsten; Foss, Nicolai, \& Vasquez, Xose (2006), "Tying The Manager's Hands': Constraining Opportunistic Managerial Intervention”, Cambridge fournal of Economics, vol. 30, n 5, pp. 797-818.

Freeman, Chris \& Soete, Luc (1997), The Economics of Industrial Innovation, Psychology Press, New York.

Freeman, Chris (1982), Economics of Industrial Innovation, Routledge, London.

Gant, John; Ichniowski, Casey\& Shaw, Cathryn (2002), "Social Capital and Organizational Change in Hihg-Involvement and Traditional Work Or- 
INNOVATION IN CORPORATE ORGANIZATIONAL CULTURE: DIVERSITY, MOTIVATION AND ORGANIZATIONAL PRESSURE AS POSSIBLE REALITIES

ganization”, fournal of Economic \& Management Strategy, vol. 11, nº 2, pp. 289328.

Garzón, Manuel Alfonso (2005), Propuesta de modelo intraemprendedor para la innovación en organizaciones perdurables, Universidad del Rosario, Bogotá.

Gherardi, Silvia; Nicolin, Davidi \& Odella, Francesca (1998), “Toward a Social Understanding of How People Learn in Organizations The Notion of Situated Curriculum", Management Learning, vol. 3, pp. 273-297.

Gioia, Dennis A.; Schultz, Majken \& Corley, Kevin G. (2000), “Organizational Identity, Image, And Adaptive Instability", Academy of Management Review, vol. 25, n 1, pp. 63-81.

Kanter, J. (1984), Management Information Systems, Upper Saddle River, Prentice Hall.

Kanter, Rosabeth Moss (1984), Change Masters, Simon and Schuster, New York.

Kline, Stephen J. \& Rosenberg, Nathan (1986), "An Overview of Innovation”, in Landau, Ralph \& Rosenberg, Nathan (Eds.), The Positive Sum Strategy: Harnessing Technology for Economic Growth, The National Academies Press, Washington , pp. 275-305.

Kotter, John P. (1995), "Leading the Change: Why Transformations Efforts Fail", Harvard Business Review, vol. 73, pp. 59.67.

Kotter, John (1996), "Liderando el cambio. Por qué fracasan los esfuerzos de transformaciones", en https://scholar.google.es/scholar.

Kotler, Philip (2011), El marketing según Kotler: cómo crear, ganar y dominar los mercados, Paidós, Barcelona.

Lank, Elizabeth \& Mayo, Andrew (2003), Las organizaciones que aprenden (the power of learning), Gestión 2000, Barcelona.

Lazonick, William \& O'Sullivan, Mary (2000), "Maximizing Shareholder Value: a New Ideology for Corporate Governance", Fournal Economy and Society, vol. 29, nº 1, pp. 13-35.

Macías Cardona, Hugo A. (2011), "Innovación y responsabilidad social: una reflexión sobre los puntos de encuentro",Universidad y Empresa, vol. 13, no 21, pp. 13-35. 
Mathew, George E. (2010), India's Innovation Blueprint: How the Largest Democracy is Becoming an Innovation Superpower, Chandos Publishing, Cambridge.

Mintzberg, Henry (2007), "Productivity Is Killing American Enterprise", Harvard Bussines Review, vol. 7-8.

Mumford, Michael \& Simonton, Dean Keith (1997), "Creativity in the Workplace: People, Problems, and Structures”, The fournal Of Creative Behavior, vol. 31, n 1, pp. 1-6.

Nelson, Richard R. \& Winter, Sidney G. (2002), "Evolutionary Theorizing In Economics", Fournal of Economic Perspectives, vol. 16, n 2, pp. 23-46.

Nonaka, Ikujiro \& Takeuchi, Hirotaka (1995), The Knowledge-Creating Company: How Japanese Companies Create the Dynamics of Innovation, Oxford university Press, Oxford.

Orlikowski, Wanda J. (1996), "Improvising Organizational Transformation Over Time: A Situated Change Perspective", Information Systems Research, vol. 7, $\mathrm{n}^{\circ}$ 1, pp. 63-92.

Pavitt, Keith (2005), "Innovation Processes", in The Oxford Handbook of Innovation, Oxford University Press, https://www.oxfordhandbooks.com /view/10.1093/oxfordhb/9780199286805.001.0001/oxfordhb9780199286805-e-4.

Pedler, Mike J.; Boydell, Tom \& Burgoyne, John G. (1989), "The Learning Company", Studies in Continuing Education, vol. 11, n 2, pp. 91-101.

Pérez, Carlota (2001), Cambio tecnológico y oportunidades de desarrollo como blanco móvil. Digital Repository Economy Commission for Latin American and Caribbean.

Pérez-López, Juan Antonio (1985), Las motivaciones humanas, IESE, Barcelona.

Prats, $M^{a}$ Julia; Siota, Josemaria; Canonici, Tommaso \& Contijoch, Xavier (2018), "Open Innovation: Building, Scaling and Consolidating Your Firm's Corporate Venturing Unit”, IESE.

Rand, Ayn (1963), For the New Intellectual: The Philosophy of Ayn Rand, Penguin, London. 
Rycroft, Robert \& Kash, Don E. (2002), "Path Dependence in The Innovation of Complex Technologies", Echnology Analysis \& Strategic Management, vol. 14, $\mathrm{n}^{\circ} 1$, pp. 21-35.

Scheine, Edgard H. (1998), La cultura empresarial y el liderazgo: una visión dinámica, Plaza y Janes, Barcelona.

Schumpeter, Joseph A. (2002), Ciclos económicos: análisis teórico, histórico y estadístico del proceso capitalista, (J. Pascual, Trans.) Universidad de Zaragoza, Zaragoza.

Spender, J. C. (1996), “Conocimiento organizacional, el aprendizaje y la memoria:. Tres conceptos en busca de una teoría diaria de la gestión del cambio organizacional”, Strategic Management fournal, vol. 17, n 2, pp. 45-62.

Taylor, Frederick \& Fayol, Henry (1987), Administración industrial y general: coordinación control previsión organización mando, El Ateneo, Buenos Aires.

Teece, David J.; Pisano, Gary \& Shuen, Amy (1997), "Dynamic Capabilities and Strategic Management", Strategic Management Fournal, vol. 18, nº 7, pp. 509-533

Tsoukas, Haridimos \& Chia, Robert (2002), "On Organizational Becoming: Rethinking Organizational Change”, Organization Science, vol. 13, $\mathrm{n}^{\circ}$ 5, pp. 567-582.

Valente, Thomas W. \& Rogers, Everett M. (1995), “The Origins and Development of the Diffusion of Innovations Paradigm as an Example of Scientific Growth", Science Communication, vol. 16, n³ 3, pp. 242-73.

Van de Ven, Andrew H.; Polley, Douglas E.; Garud, Raghu \& Venkataraman, Sankaran (1999), The Innovation Journey, Oxford University Press, New York.

Weick, Karl E.; Sutcliffe, Kathleen M., \& Obstfeld, David (2005), "Organizing and the Process of Sensemaking”, Organization Science, vol. 16, n ${ }^{\circ}, 4$, pp. 409-421.

Wenger, Etienne (1998), Las comunidades de práctica: Aprender, significado e identidad, Cambridge University Press, Cambridge. 
